\title{
Uplifting the Potential of Kinta Valley Post-Industrial Mining Landscape for World Heritage Nomination
}

\author{
Suriati Ahmad 1, Nadiyanti Mat Nayan 1, David S. Jones ${ }^{2}$
}

1 Department of Landscape Architecture, Faculty of Architecture, Planning, and Surveying,

Universiti Teknologi MARA, 32610 Seri Iskandar, Perak Darul Ridzuan, Malaysia

${ }^{2}$ Foundation Professor - Planning \& Landscape Architecture Programs, School of Architecture \&

Built Environment, Deakin University, Geelong Waterfront Campus, Geelong VIC 3220 Australia

suria564@uitm.edu.my,nadiy028@uitm.edu.my, david.jones@deakin.edu.au

\begin{abstract}
The distinct landscape of the Kinta Valley is undeniably unique in its ability to narrate significant processes in Peninsular Malaysia's history and culture. Tin mining brought about massive development to the Valley's landscape, evidenced in the making of modern Kinta and Kampar Districts today. The focus of this paper is accordingly upon the potential of Kinta Valley as a World Heritage Listed mining cultural landscape having regard to the status of derelict mining sites internationally and their inclusion on the World Heritage List. The rich cultural tapestry that is evident today provides a significant living heritage platform to understand and appreciate the diversity of Malaysia's cultural landscapes.
\end{abstract}

Keywords: Cultural Landscape as Heritage; Heritage Conservation; Post-Industrial Mining Landscape; Kinta Valley.

eISSN 2514-751X @ 2019. The Authors. Published for AMER, ABRA \& cE-Bs by E-International Publishing House, Ltd., UK. This is an open-access article under the CC BY-NC-ND license (http://creativecommons.org/licenses/by-nc-nd/4.0). Peerreview under responsibility of AMER (Association of Malaysian Environment-Behaviour Researchers), ABRA (Association of Behavioural Researchers on Asians) and cE-Bs (Centre for Environment-Behaviour Studies), Faculty of Architecture, Planning \& Surveying, Universiti Teknologi MARA, Malaysia.

DOI: https://doi.org/10.21834/aje-bs.v4i14.356 


\subsection{Introduction}

The global Industrial Revolution era marked a significant change in the Malaysian landscape before the close of the $19^{\text {th }}$ century. Massive social structural and cultural changes took place during the tin mining rushes that the Malaysian landscape facilitated. This new land exploitation arrangement resulted in significant advances in mining technological advancement and the establishment of modern transportation networks. These transformative patterns and technologies are the crucial factors that permeate and characterise the successful working processes of this industry. From a cultural heritage perspective, it is therefore essential to understand the complexity and nature of mining exploration at this place in expressing historical, scientific, social and cultural values, and incorporate such into statements of significance, heritage registrations, and management plans and strategies. This scope should include both its tangible and intangible qualities in any assessment (Ahmad, 2018; American Society of Landscape Architects, 2010; Lennon, 1997; Pearson \& McGowan, 2000, 2009; Smith \& Lawrence, 2018).

Regardless of their often-ruinous characteristics, these unique industrial landscapes portray the very nature of mining exploration, exploitation, and their relationship to the global industrialisation phenomena. In particular, mining landscapes also evidence a remarkable tapestry of social and cultural processes that are embodied within this landscape type. The international heritage community, in recent years, has acknowledged that industrial mining landscapes are one important cultural manifestation. Such is demonstrated in the inscription of Las Mèdulas, Spain, onto World Heritage List in 1997 (Smith \& Lawrence, 2018). Las Mèdulas' rationale for inscription was on the basis that:

In the 1st century A.D., the Roman Imperial authorities began to exploit the gold deposits of this region in north-west Spain, using a technique based on hydraulic power. After two centuries of working the deposits, the Romans withdrew, leaving a devastated landscape. Since there was no subsequent industrial activity, the dramatic traces of this remarkable ancient technology are visible everywhere as sheer faces in the mountainsides and the vast areas of tailings, now used for agriculture (UNESCO 1997, p.1).

This is the first derelict industrial landscape inscribed onto the World Heritage List. This inscription further underpins changes in heritage interpretation and perspectives that point to a recognition that industrialisation is a integral part of our human culture and its activities. Thus, industrial landscapes are an expression of this culture.

The most recent industrial landscape inscribed by UNESCO in July 2019, is the Ombilin Coal Mining Heritage of Sawahlunto, in adjacent Indonesia. Its rationale for inscription was because:

Built for the extraction, processing and transport of high-quality coal in an inaccessible region of Sumatra, this industrial site was developed by the Netherlands' colonial government from the late 19th to the beginning of the 20th century with a workforce recruited from the local population and supplemented by convict labour from Dutch-controlled areas. It comprises the mining site and company town, coal storage facilities at the port of Emmahaven and the railway network linking the mines to the coastal facilities. The Ombilin Coal Mining Heritage was built as an integrated system that enabled the efficient deep-bore extraction, processing, transport and shipment of coal (UNESCO 2019, p.1).

Increasingly since 1997 the international heritage community (e.g. ICOMOS, TICCIH, UNESCO, etc.) has articulated their growing acceptance and recognition of the heritage 
values embedded in mining cultural landscapes (see industrial mining landscapes recognition on the UNESCO World Heritage List). Ahmad (2018) argues that Malaysian legislation has failed to keep pace with these global changes. This is resulting in only heritage item or site recognition being applied in Malaysia (National Heritage Department, 2018; The Commissioner of Law Revision, 2006). Thus, there is an absence of any national heritage recognition of mining landscapes in Malaysia that comprising part of this country's cultural heritage legacy (Ahmad \& Jones, 2015b). Further, the legal text limitations contained in Malaysian National Heritage Act 2005, together with the Malaysian National Landscape Policy that currently focuses only on natural landscapes albeit with a cultural dimension (NLP, 2014, pp.27-29), are more underpinned by tourism activities and aspirations than by heritage conservation aims. The National Heritage Act 2005 only recognises significant buildings, monuments, objects, and archaeological sites, and the National Landscape Policy only covers matters on landscape development and protections in Malaysia.

These limitations, of Malaysian national legislation and policy towards heritage values, are firstly reflected in the Malaysian Government's limited engagement with the UNESCO World Heritage List and secondly in the shortage of Malaysian Government submissions to the UNESCO World Heritage Tentative List tending to concentrate only upon natural landscape protection (see Table 1). Considering the potential of Kinta Valley to demonstrate significant evidence and values about Malaysia's industrial mining landscape and cultural heritage (Ahmad (2018), this absence of inclusion is palpable. Therefore, this paper offers a significant insight towards re-charting this focus.

Table 1: Malaysia UNESCO World Heritage List and Tentative List

\begin{tabular}{|c|l|l|}
\hline No. & \multicolumn{1}{|c|}{ UNESCO World Heritage List } & \multicolumn{1}{c|}{ UNESCO Tentative List } \\
\hline 1. & $\begin{array}{l}\text { Gunung Mulu National Park, Sarawak (natural } \\
\text { landscape); Date of Inscription: 2010; Criteria: } \\
\text { (vii)(viii)(ix)(x) }\end{array}$ & $\begin{array}{l}\text { FRIM Selangor Forest Park (cultural landscape) } \\
\text { Date of Submission: 23/02/2017; Criteria: (v) }\end{array}$ \\
\hline 2. & $\begin{array}{l}\text { Kinabalu Park, Sabah (natural landscape) } \\
\text { Date of Inscription: 2000; Criteria: (ix)(x) }\end{array}$ & $\begin{array}{l}\text { Gombak Selangor Quartz Ridge (natural landscape) } \\
\text { Date of Submission: 23/02/2017; Criteria: (vii) }\end{array}$ \\
\hline 3. & $\begin{array}{l}\text { Melaka and George Town, Historic Cities of the } \\
\text { Straits of Malacca (cultural landscape) } \\
\text { Date of Inscription: 2008; Criteria: (ii)(iii)(iv) }\end{array}$ & $\begin{array}{l}\text { National Park (Taman Negara) of Peninsular } \\
\text { Malaysia (natural landscape) } \\
\text { Date of Submission: 05/06/2014; Criteria: (ix)(x) }\end{array}$ \\
\hline 4. & $\begin{array}{l}\text { Archaeological Heritage of the Lenggong } \\
\text { Valley, Perak (cultural landscape) } \\
\text { Date of Inscription: 2012; Criteria: (iii)(iv) }\end{array}$ & $\begin{array}{l}\text { Royal Belum State Park (natural landscape) } \\
\text { Date of Submission: 23/02/2017; Criteria: (x) }\end{array}$ \\
\hline
\end{tabular}

Source: Reproduced from Ahmad (2018, p. 8).

\subsection{The Post-Industrial Mining Landscape}

The idea of a cultural landscape has expanded from the middle of the $20^{\text {th }}$ century, reaching the international heritage community before being finally accepted by the UNESCO World Heritage Convention in 1992 (Rössler, 2015). The latter's definition recognises the 'combined works of nature and of man, as stated in Article 1 of the World Heritage Convention (UNESCO, 2017, p. 81). This concept further recognises humans as being the shaping force of Earth's natural landscapes. Thus, cultural processes (Roe \& Taylor, 2014; Taylor, 2009, 
2017) that blend within each layer of a 'landscape' can be documented through each World Heritage inscribed cultural landscape property globally today.

Hardesty and Little (2009) assert that industrial activity constructs distinctive visual landscapes, most commonly in rural areas or landscapes. McClelland, cited in Hardesty and Little (2009, p. 132), argues that historic rural landscapes 'are created not by intention or design but by [a] repetition of the same human activities in the same place'. Industrial landscapes are therefore geographical precincts or places that have been altered by humans through industrial activities. Such places have re-fashioned landscapes resulting in cumulative layers of industrial fabric evidenced in multiple landscape spatial settings, land uses, ecological and natural responses to industrial practices, as well as possessing evidence of distinct human cultural traditions that scaffolded these industrial processes (Hardesty \& Little 2009; Pearson \& McGowan 2009).

Pearson and McGowan (2000; 2009, p. 210) stress that 'whole landscape settings' where mining industrialization has occurred most often portray a notable and particular industrial character that distinguishes its cultural significance. Such characteristics give rise to the unique identity of historic mining places and or landscapes. Thus, significant mining places are rich in heritage values (including both tangible and intangible qualities) that warrant particular protection actions and management strategies. To Pearson and McGowan (2009, p. 210), heritage elucidates 'things we want to keep, enjoy or learn from, and pass on to the next generation - includes many aspects of our cultural environment, among them being mining places'. This is particularly relevant to historic mining sites that possess tangible evidence that exhibits past extractive mining activities and processes that include mine workings, machinery, quarries, shafts, bridges, roads/tracks, dams, surface dumps, slag heaps, surface structures and settlement patterns (Ahmad \& Jones, 2015a; Ballinger, 2012; Drew, 2012).

\subsection{From Scenic Quality to Recognizing the Value of Ruinous Landscape: The Shift of Heritage Perspectives}

Post-industrial mining landscapes possess a rich cultural tapestry that manifests and evidences human responses and stewardship actions and policies towards the subject environment. Due to the nature of mining, that crafts a significant visual impact upon a landscape, this dramatic scene is what Storm $(2014$, p. 1) describes as a post-industrial 'landscape scar'. Perhaps the 'wound' and 'scar' labels used by Storm (2014) are metaphoric references to dramatize the hazardous, polluted, and abandoned-ground nature of open-pit mines and or ruined industrial sites that are today extant neglected and forgotten tracts of landscape and countryside. Regardless of these negative perspectives and unpleasant scenarios, these 'scars' trigger individual and community nostalgic memories, and awaken recollections of past mining experiences and lives, thus recalling the feeling of 'sorrow and betrayal, of the abuse of power and latent hazards' caused by industrial activities (Storm, 2014, p. 1). Noble and Spude (1992, p. 13) argue that mining landscapes 'evoke images of time, place, and historical patterns associated with past mining epochs'. Therefore, the heritage values embedded within post-industrial landscapes 'convey ambiguous and complex pasts about injustice and fear, along with survival, resilience, and courage [...] they are 
physical reminders of something' (Storm, 2014, p. 1). Spatial patterns emerge as a consequence of mining activities. These can reflect cultural processes in a landscape and depict significant heritage values that genuinely describe and express a mining cultural landscape. Evidence of this claim, of being able to represent through World Heritageinscribed properties, has seen the shift of World Heritage nominations from the year 2000 with the inscription of the Blaenavon Industrial Landscape in the United Kingdom.

\subsection{The Dearth of Heritage Mining Cultural Landscape Study from Malaysia and South East Asia Region}

Australia ICOMOS's Burra Charter underscores that cultural significance 'is embodied in the place itself, its fabric, setting, use, associations, meanings, records, related places and related objects' (Australia ICOMOS, 2013, p. 2). Five important cultural values, established through this Charter, define cultural association and the merits that bind areas, places, or landscapes including their 'aesthetic, historic, scientific, social and or spiritual values' (Australia ICOMOS, 2013). The Joint ICOMOS-TICCIH $(2011$, p. 1) further asserts that industrial mining landscapes consist of fabric that evidences 'production, transportation and power-generating or harnessing process and technologies, trade and commercial interactions, and new social and cultural patterns [together with intangible dimensions that connect] skills, memories and social life of workers and their communities'.

In examining abandoned mining landscapes inscribed on the World Heritage List, it is very evident that a notable gap exists in the South-East Asian Region relating to cultural landscape properties. Taylor (2017) believes that more significant cultural landscape properties, especially mining landscapes in Asia, have yet to be identified and assessed. Of current World Heritage List inscriptions, Ahmad (2018) concludes that only one industrial mining landscape in Asia (Iwami Ginzan Silver Mine and its Cultural Landscape) has been inscribed on the World Heritage List. This statistically conclusion raises the spectre that there could be more industrial mining landscapes in Asia, and specifically in South-East Asian Region (Smith \& Lawrence, 2018; UNESCO, 2018) worthy of consideration (see Table 2). The July 2019 inscribed Ombilin Coal Mining Heritage of Sawahlunto cultural property in Indonesia can now be added to this very shortlist.

Table 2: World Heritage List for Industrial Mining Properties.

\begin{tabular}{|c|c|c|c|c|c|c|}
\hline Property & $\begin{array}{c}\text { Year } \\
\text { Inscribed }\end{array}$ & $\begin{array}{c}\text { Mined } \\
\text { Materia } \\
\text { I }\end{array}$ & $\begin{array}{l}\text { Time } \\
\text { Period }\end{array}$ & $\begin{array}{l}\text { World } \\
\text { Heritage } \\
\text { Criteria }\end{array}$ & $\begin{array}{l}\text { Cultural } \\
\text { Landscap } \\
\text { e (CL) }\end{array}$ & $\begin{array}{c}\text { Serial } \\
\text { Propertyl } \\
\text { No. } \\
\text { Component } \\
\text { s }\end{array}$ \\
\hline $\begin{array}{l}\text { Wieliczka and Bochnia } \\
\text { Royal Salt Mines, } \\
\text { Poland } \\
\end{array}$ & $\begin{array}{l}1978, \\
2013\end{array}$ & Salt & $\begin{array}{c}13^{\text {th }}-20^{\text {th }} \\
\text { century }\end{array}$ & (iv) & - & $\begin{array}{c}3 \\
\text { components } \\
(2013) \\
\end{array}$ \\
\hline $\begin{array}{l}\text { Historic Town of Ouro } \\
\text { Preto, Brazil }\end{array}$ & 1980 & Gold & $17^{\text {th }}-19^{\text {th }}$ & (i) (iii) & - & - \\
\hline $\begin{array}{l}\text { Røros Mining Town } \\
\text { and the } \\
\text { Circumference, } \\
\text { Norway }\end{array}$ & $\begin{array}{l}1980, \\
2010\end{array}$ & Copper & $17^{\text {th }}-20^{\text {th }}$ & (iii) (iv) (v) & $\begin{array}{c}\text { Yes } \\
(2010)\end{array}$ & $\begin{array}{c}3 \\
\text { components } \\
(2010)\end{array}$ \\
\hline
\end{tabular}




\begin{tabular}{|c|c|c|c|c|c|c|}
\hline $\begin{array}{l}\text { From the Great } \\
\text { Saltworks of Salins- } \\
\text { les-Bains to the Royal } \\
\text { Saltworks of Arc-et- } \\
\text { Senans, the } \\
\text { Production of Open- } \\
\text { pan Salt, France }\end{array}$ & $\begin{array}{l}1982, \\
2009\end{array}$ & Salt & $\begin{array}{l}\text { Middle } \\
\text { ages- } 20^{\text {th }} \\
\text { century }\end{array}$ & (i) (ii) (iv) & - & - \\
\hline City of Potosi, Bolivia & 1987 & Silver & $\begin{array}{c}16^{\text {th }} \\
\text { century }\end{array}$ & (ii) (iv) (vi) & - & - \\
\hline $\begin{array}{l}\text { Historic Town of } \\
\text { Guanajuato and } \\
\text { Adjacent Mines, } \\
\text { Mexico }\end{array}$ & 1988 & Silver & $\begin{array}{c}16^{\text {th }}-18^{\text {th }} \\
\text { century }\end{array}$ & (i) (ii) (iv) (vi) & & \\
\hline $\begin{array}{l}\text { Mines of } \\
\text { Rammelsberg and } \\
\text { Historic Town of } \\
\text { Goslar and the Upper- } \\
\text { Hartz water } \\
\text { Management System, } \\
\text { Germany }\end{array}$ & $\begin{array}{l}1992, \\
2008 . \\
2010\end{array}$ & $\begin{array}{l}\text { Metal } \\
\text { ore }\end{array}$ & $\begin{array}{l}\text { Middle } \\
\text { ages to } \\
\text { end of } 20^{\text {th }} \\
\text { century }\end{array}$ & (i) (ii) (iii) (iv) & - & $\begin{array}{c}5 \\
\text { components } \\
(2010)\end{array}$ \\
\hline $\begin{array}{l}\text { Historic Centre of } \\
\text { Zacatecas, Mexico }\end{array}$ & 1993 & Silver & $\begin{array}{l}16^{\text {th }}-17^{\text {th }} \\
\text { centuries }\end{array}$ & (ii) (iv) & - & - \\
\hline $\begin{array}{l}\text { Historic Town of } \\
\text { Banská Štiavnica and } \\
\text { the Technical } \\
\text { Monuments in its } \\
\text { Vicinity, Slovakia }\end{array}$ & 1993 & $\begin{array}{l}\text { Silver/ } \\
\text { Gold }\end{array}$ & Medieval & (iv) (v) & - & - \\
\hline $\begin{array}{l}\text { Kutná Hora: Historical } \\
\text { Town Centre with the } \\
\text { Church of St Barbara } \\
\text { and the Cathedral of } \\
\text { Our Lady at Sedlec, } \\
\text { Czech Republic }\end{array}$ & 1995 & Silver & $\begin{array}{l}14^{\text {th }}-18^{\text {th }} \\
\text { centuries }\end{array}$ & (iii) (iv) & - & - \\
\hline Las Médulas, Spain & 1997 & Copper & $\begin{array}{c}1 \text { st } \\
\text { Century }\end{array}$ & (i) (ii) (iii) (iv) & Yes & - \\
\hline $\begin{array}{l}\text { Hallstatt-Dachstein / } \\
\text { Salzkammergut } \\
\text { Cultural Landscape, } \\
\text { Austria }\end{array}$ & 1997 & Salt & $\begin{array}{c}2^{\text {nd }} \text { mill BC } \\
-20^{\text {th }} \\
\text { centuries }\end{array}$ & (iii) (iv) & Yes & - \\
\hline $\begin{array}{l}\text { Historic Centre of the } \\
\text { Town of Diamantina, } \\
\text { Brazil }\end{array}$ & 1999 & $\begin{array}{l}\text { Diamon } \\
\text { ds }\end{array}$ & $\begin{array}{c}18^{\text {th }} \\
\text { century }\end{array}$ & (ii) (iv) & - & - \\
\hline $\begin{array}{l}\text { Blaenavon Industrial } \\
\text { Landscape, United } \\
\text { Kingdom }\end{array}$ & 2000 & $\begin{array}{l}\text { Iron / } \\
\text { Coal }\end{array}$ & $\begin{array}{c}19^{\text {th }} \\
\text { century }\end{array}$ & (iii) (iv) & Yes & - \\
\hline $\begin{array}{l}\text { Neolithic Flint Mines at } \\
\text { Spiennes, Belgium }\end{array}$ & 2000 & Flint & Neolithic & (i) (iii) (iv) & - & - \\
\hline $\begin{array}{l}\text { Zollverein Coal Mine } \\
\text { Industrial Complex in } \\
\text { Essen, Germany }\end{array}$ & 2001 & Coal & $\begin{array}{c}19^{\text {th }}-20^{\text {th }} \\
\text { century }\end{array}$ & (ii) (iii) & - & - \\
\hline $\begin{array}{l}\text { Mining Area of the } \\
\text { Great Cooper } \\
\text { Mountain in Falun, }\end{array}$ & 2001 & Copper & $\begin{array}{l}13^{\text {th }} 17^{\text {th }} \\
\text { century }\end{array}$ & (ii) (iii) (v) & Yes & - \\
\hline
\end{tabular}


Ahmad, S., et.al. / Asian Journal of Environment-Behaviour Studies (ajE-Bs), 4(14) Sep / Dec 2019 (pp.81-95)

\begin{tabular}{|c|c|c|c|c|c|c|}
\hline Sweden & & & & & & \\
\hline $\begin{array}{l}\text { Humberstone and } \\
\text { Santa Laura Saltpeter } \\
\text { Works, Chile }\end{array}$ & 2005 & $\begin{array}{c}\text { Saltpete } \\
\text { r }\end{array}$ & $\begin{array}{l}19^{\text {th }}-20^{\text {th }} \\
\text { centuries }\end{array}$ & (ii) (iii) (iv) & - & - \\
\hline $\begin{array}{l}\text { Sewell Mining Town, } \\
\text { Chile }\end{array}$ & 2006 & Copper & $\begin{array}{l}20^{\text {th }} \\
\text { century }\end{array}$ & (ii) & - & - \\
\hline $\begin{array}{l}\text { Cornwall and West } \\
\text { Devon Mining } \\
\text { Landscape, United } \\
\text { Kingdom }\end{array}$ & 2006 & $\begin{array}{l}\text { Copper } \\
\text { and Tin }\end{array}$ & $\begin{array}{l}18^{\text {th }}-19^{\text {th }} \\
\text { century }\end{array}$ & (ii) (iii) (iv) & Yes & $\begin{array}{c}10 \\
\text { components }\end{array}$ \\
\hline $\begin{array}{l}\text { Iwami Ginzan Silver } \\
\text { Mine and its Cultural } \\
\text { Landscape, Japan }\end{array}$ & $\begin{array}{l}2007 \\
2010\end{array}$ & Silver & $\begin{array}{l}16^{\text {th }}-20^{\text {th }} \\
\text { centuries }\end{array}$ & (ii) (iii) (v) & Yes & $\begin{array}{c}14 \\
\text { components }\end{array}$ \\
\hline $\begin{array}{l}\text { Major Mining Sites of } \\
\text { Wallonia, Belgium }\end{array}$ & 2012 & Coal & $\begin{array}{c}19^{\text {th }} \text { and } \\
20^{\text {th }} \\
\text { centuries }\end{array}$ & (ii) (iv) & - & $\begin{array}{c}4 \\
\text { components }\end{array}$ \\
\hline $\begin{array}{l}\text { Nord-Pas-de-Calais } \\
\text { Mining Basin, France }\end{array}$ & 2012 & Coal & $\begin{array}{l}1700 \mathrm{~s}- \\
1900 \mathrm{~s}\end{array}$ & (ii) (iv) (vi) & Yes & $\begin{array}{c}109 \\
\text { components }\end{array}$ \\
\hline $\begin{array}{l}\text { Heritage of Mercury, } \\
\text { Almaden and Idrija, } \\
\text { Spain and Slovenia }\end{array}$ & 2012 & Mercury & $\begin{array}{l}\text { Antiquity } \\
\text { to present }\end{array}$ & (ii) (iv) & - & $\begin{array}{c}2 \\
\text { components }\end{array}$ \\
\hline $\begin{array}{l}\text { Sites of Japan's Meiji } \\
\text { Industrial Revolution: } \\
\text { Iron and Steel, } \\
\text { Shipbuilding and Coal } \\
\text { Mining, Japan }\end{array}$ & 2015 & Coal & $\begin{array}{l}19^{\text {th }} \text { and } \\
\text { early } 20^{\text {th }} \\
\text { century }\end{array}$ & (ii) (iv) & - & $\begin{array}{c}23 \\
\text { components }\end{array}$ \\
\hline $\begin{array}{l}\text { Ombilin Coal Mining } \\
\text { Heritage of } \\
\text { Sawahlunto, Indonesia }\end{array}$ & 2019 & Coal & $\begin{array}{l}19^{\text {th }} \text { and } \\
\text { early } 20^{\text {th }} \\
\text { century }\end{array}$ & (ii)(iv) & Yes & unclear \\
\hline
\end{tabular}

Source: Smith and Lawrence quoted in Ahmad (2018, pp. 58-59) with author modifications and updates that highlighted the analysis of World Heritage Cultural Landscape Properties.

\subsection{Research Design and Strategy}

In general, this research applied a mixed-method approach. The central investigatory strand of this research methodology remains qualitative through the use of exploratory sequential design. However, in documenting the Kinta Valley industrial mining landscape characteristics and its associated features, various qualitative methods were used for data collection. Included were a series of site surveys and observations for primary data collection. Additionally, a focus group workshop was conducted seeking to establish and confirm expert perceptions about the extant mining fabric that is still intact in Kinta Valley. Documentary research through secondary data collection was undertaken, including library searches for historical and archival records in Malaysia, reviewing the relevant period and contemporary government reports and documents and the use of geospatial data analysis to enable a comprehensive reading and mapping of the landscape. These research tasks completing the first and second phase analysis of the research. 


\subsection{Findings}

\subsection{The Cultural Landscape Assessment of Kinta Valley}

Exploring the tracery of human interventions, and social responses to this environment have exposed the Valley's rich cultural tapestry. This tapestry is linked to tin mining exploitation that possesses extant tangible and intangible forms and meanings enabling their evaluation as to their heritage values and merits (Ahmad \& Jones, 2015a). In the case of Kinta Valley, its geological ground, that is rich with alluvial tin deposits, the historical pattern of human mining exploitation in the Valley has crafted a significant and particularly unique spatial organization. This includes the establishment of 22 old clustered settlements that remains today. Due to this particular clustered setting, the existence of a mixed cultural community underpinned by religious beliefs distinguishes a unique spatial environment visually and tangibly characterised by sacred places, villages and cemeteries extant today. It is therefore apparent that when Relph defines 'place' as being 'identity composed of three interrelated components or 'physical features or appearances, observable activities and functions, and meaning or symbol' (cited in Taylor, 2008, p. 5), that this translates into the extant built environment tangible fabric of Kinta Valley. This fabric includes the Valley's continuity of tangible and intangible cultural traditions and practices that directly influences the current physical form and historical development of this cultural landscape.

Further, in the act of accommodating historical layers of mining activities and their technological advances, new circulation networks (consisting of roads and railways) were constructed from the 1880s onwards connecting all-important mining areas to aid the efficient movement of extracted tin ore. With this movement system established, agricultural activities together with ancillary industries (including timber mills, foundries, amang retreatment plants, etc.) were built along these newly developed roads and railway lines. These new activities manifested a remarkable and particular industrial landscape mosaic. Places like Papan-Pusing, Tronoh, Lahat, Menglembu-Ipoh, Kampar-Mambang Diawan, Batu Gajah, Tanjung Tualang-Kampung Baharu Timah and Chemor-Tanjung Rambutan significantly demonstrate this historical setting and pattern. This landscape mosaic is especially evident when viewed through Google Earth imagery. The imagery allows easy visual interpretation of the existence of mining ponds that are highly visible resulting in a specific fabric component highlighting the former land use of the Valley's boom tin mining era (see Figures $1-3$ ). With deforestation of land in the Valley due to mining activities, much of these areas today have been subject to successional vegetation and wild plant invasions, and together with sand mining activities, can be witnessed on the western and southern hillsides of Kinta Valley. Such is creating what scientists now call 'novel ecosystems'.

Hence recognising the presence of this contemporary historic mining landscape fabric together with the establishment of a significant and particularly unique landscape mosaic (see Figure 1 - Figure 3). This study has validated the existence of a mining-influenced cultural landscape (human-nature dependent) that demonstrates substantial heritage merit and identity embodying an internationally significant industrial mining cultural landscape. 


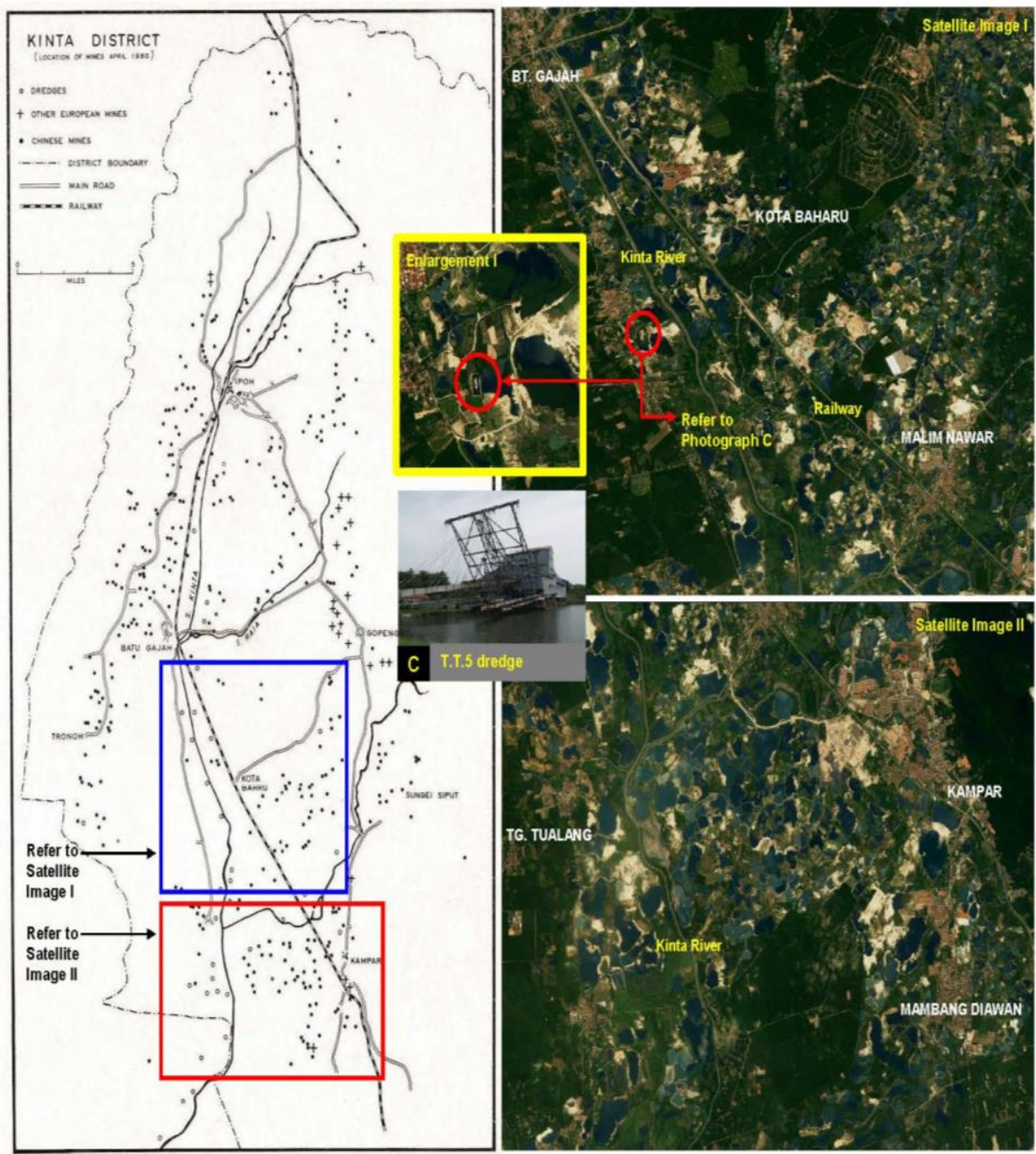

Figure 1: Different types of mining methods applied in Kinta Valley have demonstrated significant impact on its physical landscape depicted through various sizes of tailing dumps, dredge ponds and tailing retention ponds/sedimentation that are currently extant within the Kinta Valley landscape especially within the areas of Batu Gajah-Tanjung Tualang and Kota Baharu-Malim Nawar-Kampar.

Source: Reproduced figure from Ahmad (2018, p. 171). 


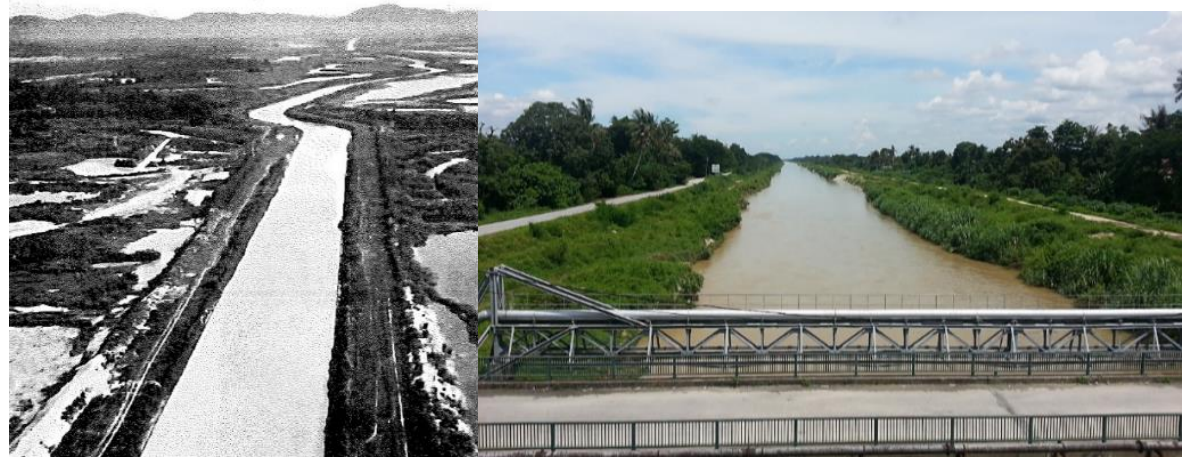

Figure 2: The canalization of Kinta River involving $61 \mathrm{~km}$ length, from Ipoh to Kuala Chenderiang. Source: Old photo reproduced from (Khoo \& Lubis, 2005, p. 325); new photo was photograph by author in 2018.

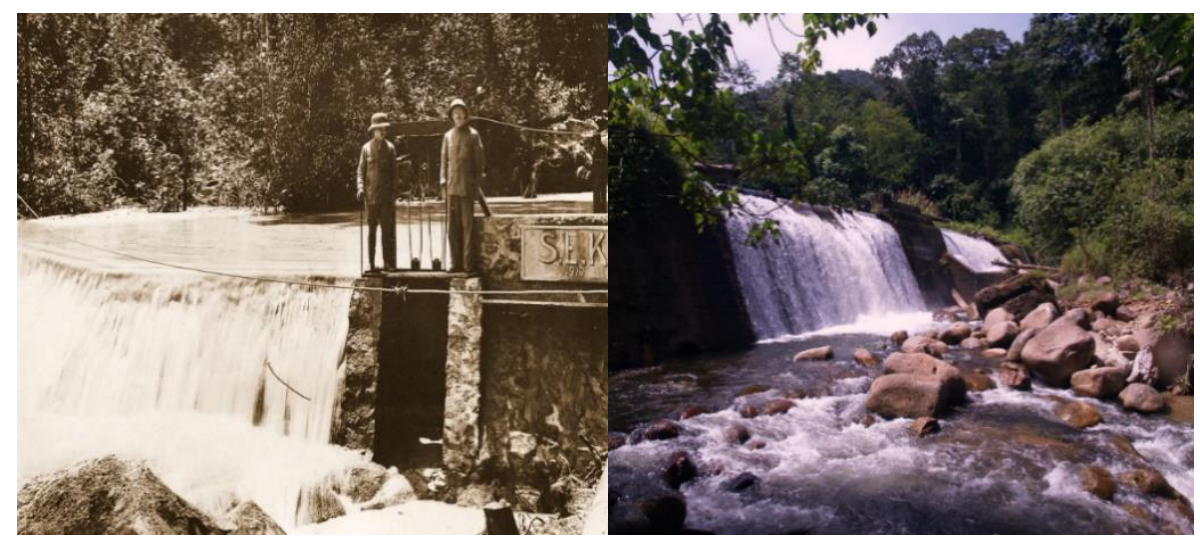

Figure 3: Field trip to the Kampar River former tin mining dam in 2014.

Source: Old photograph courtesy by Tan Sri Hew See Tong and new photo was photograph by the author in 2014 .

\subsection{Heritage Merit Embodying the Kinta Valley Ruin Landscape}

From the abovementioned five criteria embodied in the Burra Charter, it is clear that Kinta Valley possesses important cultural values in its tangible and intangible landscape attributes and places that underpins the 'historic, scientific, aesthetic, social and spiritual' qualities at local, Perak state and even Malaysian national levels. It is difficult to justify which value surpasses each other, given the complexity of the Kinta Valley industrialization. Each cultural value, as commonly interpreted in cultural heritage academic discourses, is interdependent. Interdependency includes the natural values of the Kinta Valley that provide a conducive amphitheatre setting that permeates aesthetically through the massive 
tin exploration activity areas within this landscape. The inherent qualities of the Valley reflect its physiographic setting (the lush water catchment areas in both the Keledang and Main Ranges) together with its geological ground. Both hide the Valley's rich-stanniferous alluvium tin deposits that provided the right conditions for complex mining activities and historical innovation techniques to be trialled and to prosper in Kinta Valley from the 1880s. Due to these innovations, 15 mining dams were established in the Valley's hinterland (due to availability of prolific water resources), demonstrating the integrity of the Kinta Valley natural setting that binds human thoughts and attitudes towards the perception of their environment. This resulted in Kinta Valley being the venue for successful hydraulic mining practice and innovation in Malaysia for decades, commencing from the 1890s with the successful working of Gopeng tin mines.

Mining innovation and expansion in Kinta Valley also reflects foreign investment and international technology transfer across the $19^{\text {th }}$ century further resulting in the growth of the engineering discipline in Malaysia. Additionally, with the development of 2 permanent hydro-electric power plants (although the Malim Nawar power plant is today no longer in use) were established to support mining activities, together with the channelling of $61 \mathrm{~km}$ of the Kinta River to mitigate siltation issues, that remain today, prolonged the mining expansion in the Valley. The mining activities especially enabled the sustenance of a reliable electric power supply for dredge mining along the Kinta River corridor. These extension facilities also reflect evidence of scientific knowledge development of state and national level significance.

The tangible and intangible landscape fabric remain within Kinta Valley's post-industrial mining landscape today enables heritage values to be recognized and established. A detailed cultural heritage assessment, applying five fundamental values embodied in the Burra Charter, has revealed and quantified the cultural significance of Kinta Valley. This research also concluded that all five cultural values, articulated in the Burra Charter, are present within the Kinta Valley landscape are present but that they are also interdependent. Together with the Valley's natural quality, a significant industrial landscape mosaic is evident. Although ruinous and visually derelict, this mosaic that once served as a former tin mining ground today offers 'historic, scientific and aesthetic values' that express the strong identity and cultural heritage legacy of the Kinta Valley. Further, by applying the Malaysian national heritage criteria stated in section 67 of the Malaysian National Heritage Act 2005, the Kinta Valley post-industrial mining landscape meets criteria (a), (c) and (e) demonstrating the heritage merit of the Kinta Valley as a continuing landscape of national significance.

\subsection{Discussion}

\subsection{Valuing Kinta Valley Mining Cultural Landscape as National Heritage}

The distinct landscape of Kinta Valley is undeniable. The Valley is a unique tract of land that narrates a critical phase in Peninsular Malaysia's history and culture. Included in this story is what is termed 'process history' that resulted in the massive industrialization that impacted 
this landscape and its waters. From the 1860s mining intensively commenced in Gopeng, in Perak State, and this activity slowly decreased in production over the next 150 years. But active mines (re-mining on the former mining land) continue in Kota Baharu and Malim Nawar today. In addition to the mine pits, amang retreatment plants extant in Pusing, Kampar, Malim Nawar, and Mambang Diawan demonstrate the process of tailings treatment. These tailings, the by-product of tin mining, significantly contribute to the historical and present tin extraction and production from this Valley. This extraordinary tin mining extraction phenomena continued (and continues) to shape this Valley landscape for more than 150 years. This industrial footprint, therefore, evidences the past tin mining legacy, including all its physical and cultural accoutrements, has resulted in the creation of a unique visual landscape that is Kinta Valley today. Manifest to this conclusion is that the existing post-industrial mining landscape (physical landscape) contributes to the cultural and social uniqueness of this Valley. Other than the landscape, the substantial fabric includes the natural environment (due to its physiographic setting), socio-cultural patterns and cultural traditions as well as the built heritage (including the 1880s old townships, settlements and villages) that were established as the principle built form features that dotted and characterised the present industrial image and narrative of this Valley.

Notably, these are not simply threads that construct the tangible material forms and evidence. There is additionally a remarkable spectrum of intangible values continuing today that include oral histories, beliefs, and customs that narrate the mental imagery, memories and rituals of this Valley landscape.

\subsection{Conclusion \& Recommendations}

Manifest of the remarkable industrial phenomena arising from the massive tin mining expansion in Kinta Valley for 110 years, Kinta Valley landscape possesses state, national and international levels of cultural heritage significance. Kinta Valley possesses similar if not comparable landscape patterns to several World Heritage inscribed mining cultural landscapes (e.g. Cornwall and West Devon Mining Landscape, United Kingdom; Iwami Ginzan Silver Mine and its Cultural Landscape, Japan; and, the Nord-Pas-de-Calais Mining Basin, France). Apart from being the rarest (due to its industrial landscape fabric) and the longest tin working mining region in Malaysia (for more than 150 years; the 1860s-2018), this continuity of tin mining process establishes its regional identity as well as its cultural heritage. These attributes and characteristics offer a significant platform for industrial heritage tourism development to commence and be expanded in Perak State.

Noting the significant gap from South-East Asia about World Heritage List-inscribed mining cultural landscape, this place offers a major opportunity for Malaysia to lifts its cultural heritage credentials internationally by proposing its inclusion in the Tentative World Heritage List in the future. Being the rarest and the most productive alluvial mining ground in Malaysia, and one of the core tin-mining extraction venues internationally, this landscape offers a different perspective of ore mining ground in contrast to other World Heritage Listed mining cultural landscapes especially the Cornwall and West Devon Mining Landscape, United Kingdom. With advances in mining knowledge evolution and technology expansion towards 
the end of the $19^{\text {th }}$ century, Kinta Valley mining ground has been acknowledged by many researchers as being the world's most prosperous alluvial tin producer from the end of the $19^{\text {th }}$ century (Jones, 1925; Tin Industry (Research and Development) Board (1984); Ingham \& Bradford, 1960); The Kuala Lumpur Tin Market, 2010).

\section{Acknowledgement}

This paper, in part derives from the researcher's PhD thesis entitled 'Cultural Landscape Study of the Kinta Valley Post-Industrial Mining Landscape, Malaysia' (2018) from Deakin University, Australia. Many parties have participated in this research, especially with the running of the expert focus group workshop (mapping the industrial mining elements) as well as site surveys. Special mention goes to Professor David S. Jones, who with his wisdom, has guided the researcher to accomplish with critical findings that could further benefit the Perak State government in the future.

\section{References}

Ahmad, S. (2018). Cultural landscape study of the Kinta Valley post-industrial mining landscape, Malaysia. (Doctor of Philosophy), Deakin University, Geelong, Australia.

Ahmad, S., \& Jones, D. (2015a, 5-8 November). Justifying the cultural landscape significance of the Kinta Valley post-industrial mining landscape, Malaysia. In Australia ICOMOS Conference 2015), Adelaide, Australia.

Ahmad, S., \& Jones, D. (2015b). Making sense of heritage mining landscape conservation in Malaysia: potential and challenges. In 21st International Sustainable Development Research Society Conference (ISDRS)), Geelong, Australia.

American Society of Landscape Architects. (2010). Interview with Franceso Bandarin, Director, UNESCO World Heritage. ASLA News. Retrieved from http://www. asla.org/ContentDetail.aspx?id=25842

Australia ICOMOS. (2013). The Burra Charter: the Australia ICOMOS Charter for Places of Cultural Significance 2013. Australia: Australia ICOMOS Incorporated.

Ballinger, R. (2012). Cultural landscapes training manual: a guide for historical societies. Australia: Federation of Australian Historical Societies Inc.

Drew, G. (2012). Interpreting South Australia's mining heritage. from http://www.docstoc.com/docs/117453949/Interpreting-South-Australia-Mining-Heritage ; accessed 1 July 2013.

Hardesty, D. L., \& Little, B. J. (2009). Assessing site significance: a guide for archeologists and historians. United Kingdom: Altamira Press.

Ingham, F. T., \& Bradford, E. F. (1960). Geology and mineral resources of the Kinta Valley, Perak. Malaysia: Geological Survey Headquaters.

Joint ICOMOS-TICCIH. (2011). Principle for the Conservation of Industrial Heritage Sites, Structures, Areas and Landscapes. 17th ICOMOS General Assembly, Paris: ICOMOS-TICCIH. 
Ahmad, S., et.al. / Asian Journal of Environment-Behaviour Studies (ajE-Bs), 4(14) Sep / Dec 2019 (pp.81-95)

Jones, W. R. (1925). Tinfields of the world London : Mining Publications Limited.

Khoo, S. N., \& Lubis, A. R. (2005). Kinta Valley: pioneering Malaysia's modern development: Areca Books.

Lennon, J. (1997). Case study of the cultural landscapes of the Central Victorian goldfields: Department of the Environment.

Malaysia. 2014. National Landscape Policy: Malaysia Beautiful Garden Nation. National Landscape Department Ministry of Housing and Local Government, Kuala Lumpur.

National Heritage Department. (2018). Daftar warisan. Retrieved September, 2018, from http://www.heritage.gov.my/ms/

Noble, B. J., \& Spude, R. (1992). Guidelines for identifying, evaluating, and registering historic mining properties: U.S. Department of the Interior

Pearson, M., \& McGowan, B. (2000). Mining heritage places assessment manual: Canberra : Australian Council of National Trusts : Australian Heritage Commission.

Pearson, M., \& McGowan, B. (2009). Mining sites in NSW : history and heritage Industry and Investment NSW.

Roe, M., \& Taylor, K. (2014). New cultural landscapes: emerging issues, context and themes. In M. Roe \& K. Taylor (Eds.), New cultural landscapes. London; New York: Routledge, Taylor \& Francis Group.

Rössler, M. (2015). World heritage cultural landscapes. In K. Taylor, A. S. Clair \& N. J. Mitchell (Eds.), Conserving cultural landscapes: challenges and new directions. London; New York: Routledge, Taylor \& Francis Group.

Smith, A., \& Lawrence, S. (2018). Understanding the outstanding universal value of mining sites: evolving international approaches and their implications for reconsidering the World Heritage potential of the Victorian Goldfields. Australia ICOMOS Historic Environment, 30(1), 50-63.

Storm, A. (2014). Post-industrial landscape scars. New York: Palgrave Macmillan.

Taylor, K. (2008, 29 Sept - 4 Oct). Landscape and memory: cultural landscapes, intangible values and some thoughts on Asia. In 16th ICOMOS General Assembly and International Symposium (1-14), Quebec, Canada.

Taylor, K. (2009). Cultural landscapes and Asia: reconciling international and Southeast Asian regional values. Landscape Research, 34(1), 7-31.

Taylor, K. (2017). Landscape, culture and heritage. Changing perspectives in an Asian context (Doctor of Philosophy ), Deakin University, Australia. Retrieved from http://dro.deakin.edu.au/eserv/DU:30102152/taylorlandscapeculture-2017A.pdf (dul.30102152)

National Heritage Act 2005 Act 645 (2006).

The Kuala Lumpur Tin Market. (2010). Tin story: heritage of Malaysia. Malaysia: The Kuala Lumpur Tin Market (KLTM).

Tin Industry (Research and Development) Board. (1984). Melombong timah di Malaysia [Tin mining in Malaysia]. Kuala Lumpur, Malaysia: The publicity management committee.

UNESCO. (1997). Las Mèdulas, Spain. Retrieved from: https://whc.unesco.org/en/list/803/ 
Ahmad, S., et.al. / Asian Journal of Environment-Behaviour Studies (ajE-Bs), 4(14) Sep / Dec 2019 (pp.81-95)

UNESCO. (2017). Operational guidelines for the implementation of the world heritage convention. Paris, France: UNESCO World Heritage Centre.

UNESCO. (2019). Ombilin Coal Mining Heritage of Sawahlunto, from https://whc.unesco.org/en/list/1610

UNESCO. (2018). Cultural landscapes. Retrieved July, 2018, from http://whc.unesco.org/en/culturallandscape/ 